\title{
Jesus: Sy belewing en verwerking van sy emosies
}

D A Pauw

(RAU)

\section{ABSTRACT}

Jesus: How He experiences emotions and deals with them

Emotions are experienced by every human being. Decisions and actions are inevitably influenced by these emotions. Despite possible perceptions about Jesus, He became a human amongst fellow men, experiencing and dealing with emotions in an exemplary way. These emotions, as depicted by Matthew are dealt with. His dismay, despondency and intense frustration; his anger which is repeatedly and sharply vented, as well as his love and compassion which are displayed by his words, and healings. In dealing with his intensely experienced emotions Jesus not only demonstrates that these emotions are inevitably part of human existence, but becomes the time role model for the believer regarding his handling of emotions.

\section{DOELSTELLING}

Jesus, Seun van God, het mens geword - ware en volledige mens. En tog kom die vraag op: Sit daar nie vir ons iets teenstrydigs hierin nie? Is dit moontlik om God te wees, maar ook ten volle mens? Miskien, sê ons, maar dan gekwalifiseerd: 'n "Supermens", bo-natuurlik, verhewe bo die "normale" mens. Dan leef Hy as 't ware met 'n "voorgee", nie heeltemal op ons frekwensie nie, nie so weerloos, so uitgelewer aan omstandighede soos ons gewone mense nie, nie so emosioneel of kompulsief soos ons nie.

Onwillekeurig is hierdie en soortgelyke gedagtes deel van ons opvattings oor Jesus. Daarby kom die persepsie dat Jesus beheersd was - byna bo-natuurlik - dat $\mathrm{Hy}$ baie ernstig was, allermins emosioneel, slegs af en toe aan sy gevoelens uiting gegee het. Toegegee, Hy het 'n keer gehuil met die dood van Lasarus, sy boesemvriend, het 'n slag die geldwisselaars en handelaars uit die tempel uitgejaag, die Fariseërs 'n paar keer uitgetrap, en in Getsemane doodsbenoud geraak. "Emosioneel" kan ons Hom egter kwalik noem.

Maar is só 'n persepsie van Jesus korrek? Laat dit reg geskied aan sy opdrag om volledig mens te wees op aarde? Laat dit reg geskied aan die geïntegreerdheid van sy bestaan met dié van ander, aan sy verhoudings met individue, met groepe, met skares, laat dit reg geskied aan die intensiteit 
van sy meelewing en lyding, maar ook aan sy frustrasies, sy woede en die skerpheid van sy kritiek? Die antwoord is 'n besliste NEE! Máár dan moet ons met ' $n$ oop gemoed en onbevange Jesus as mens leer ken en sien ontvou uit sy reaksies, sy woorde, sy dade, sy swye en selfs sy lyftaal. Hierdie soeke na 'n vollediger prentjie van Jesus as mens en as gevoelsmens is, vir die doeleindes van hierdie ondersoek, toegespits op Matteus se uitbeelding van Jesus se lewe en bediening. Die doel is om aan die hand van die Griekse teks aan te toon hoedat Jesus self 'n wye spektrum van emosies beleef het, en dit rasioneel beheers het of spontaan daaraan uiting gegee het. Vir elkeen wat die voorbeeld van Christus as rolmodel probeer navolg, sal hierdie studie lig werp op die onmiskenbare en kardinale rol van emosies in die gelowige se reaksies, woorde, dade en verhoudings.

\section{EMOSIES IN DIE ALGEMEEN}

Elke mens ervaar emosies, en sy reaksies, woorde en dade word noodwendig deur emosies beïnvloed. Dit volg dus dat die verloop van die geskiedenis in 'n mindere of meerdere mate bepaal word deur die gevoelens waaraan leiers en besluitnemers onvermydelik onderhewig is. Daar is emosies wat in die reël 'n gunstige uitwerking het (soos liefde, deernis, agting en blydskap) en daar is dié wat uiteraard 'n negatiewe effek het (soos woede, haat, minagting en agterdog). Wanneer die rede deur emosies oorheers word, lei dit meesal tot kompulsiewe en onverantwoordelike optrede. Daarenteen, wanneer emosies onder beheer is, volg verantwoordelike, rasionele optrede in die reël. Daar is natuurlik ook emosies wat slegs ervaar word en selde tot optrede lei, soos droefheid, entoesiasme, verbasing en verslaenheid, en die uitwerking van sulke emosies is onbeduidend! .

\section{DIE ROL VAN EMOSIES IN DIE OU TESTAMENT}

Uit 'n ontleding van emosies en hul uitwerking op die geskiedenis van Saul en Dawid (1 en 2 Samuel)2, het dit duidelik geblyk dat geen Bybelkarakter immuun is teen gevoelens en hul dikwels ingrypende effek nie. Trouens, die emosies van die hoofrolspelers het meermale 'n radikale uitwerking op die verloop van gebeure. Vrees, wat sowat $23 \%$ van die opgetekende gevalle uitmaak, bring telkens 'n beslissende wending op die slagvelde van Israel. Vrees vir die volk lei tot Saul se val (1 Sam 15:24), terwyl wedersydse vrees tussen Dawid en Absalom 'n bloedige burgeroorlog veroorsaak. Woede (14\%) lei tot kompulsiewe, irrasionele besluite en dade soos 
Saul se pogings om Dawid en sy eie seun Jonatan te dood (1 Sam 20:34), asook sy uitwissing van vyf en tagtig priesters uit wraak omdat hul Dawid gehelp het (1 Sam 22:18). In woede vermoor Abner vir Asahel, en op sý beurt val Abner voor die swaard van Joab, broer van die vermoorde (2 Sam 2:23,27). Terwyl liefde tot 'n lewenslange vriendskapsverbond tussen Dawid en Jonatan aanleiding gee (1 Sam 18:1,3), en God in liefde Salomo ryklik seën (2 Sam 12:24), lei kompulsiewe liefde en hartstog tot Dawid se owerspel met Batseba (2 Sam 11:2 ev), en tot Amnon se verkragting van sy suster Tamar waarvoor hy die hoogste tol betaal (2 Sam 13). Ook hoogmoed en minagting het negatiewe gevolge: Dit lei nie net tot Saul se verwerping deur God (1 Sam 15:23) en tot die val van die magtige Goliat nie (1 Sam 17:8 ev), maar ook tot die skokkende dood van sewentig duisend mense as straf op Dawid se selfvoldaanheid (2 Sam 24). Volgens die profeet Natan is minagting vir die woord van die Here die rede vir die Batseba-Urija-episode, as straf waarvoor Batseba se kindjie sterf en die swaard nóoit weer uit Dawid se huis wyk nie (2 Sam 12:10). Haat en afguns is die oorsaak van Saul se aanslae op Dawid se lewe, en, saam met woede, lei haat tot Absalom se moord op Amnon (2 Sam 13:22,28 en 29).

In talle gevalle is emosies egter ook blote reaksies sonder beduidende gevolge, soos smart ten tye van oorlog, Samuel se droefheid oor Saul (1 Sam 15:28,35), die volk se rou oor Samuel se dood (1 Sam 25:1) en hartseer as Saul en Jonatan sneuwel (2 Sam 1:11). Vreugde is ook dikwels 'n ervaring sonder meer: Hanna is verheug oor die geboorte van Samuel (1 Sam 2:1), die volk is in ekstase oor hul nuwe koning Saul (1 Sam 11:15), en dans van vreugde met die terugkeer van die ark (2 Sam 6:12-15). Dergelike emosies kan egter ook die gang van sake positief beïnloed: Hanna se smart oor haar kinderloosheid lei tot verootmoediging, 'n eed en haar toewyding van Samuel aan die diens van die Here (1 Sam 1:10,11). Saul se berou lei telkens tot versoening tussen hom en Dawid (1 Sam 24:19; 26:21), terwyl Dawid se bittere berou oor die Batseba-episode meebring dat God hom vergewe en sy lewe spaar (2 Sam 12:13). Ook medelye kan 'n gunstige wending aan gebeure gee: Jonatan proe heuning en moet sterf. Uit meegevoel maak die volk egter beswaar en red sy lewe (1 Sam 14:45). Ten spyte van wat hul verdien, laat Dawid se deernis hom die lewens spaar van Simeï (2 Sam 19:23) en van Mefiboset (2 Sam 19:29).

Dit blyk dus duidelik dat emosies van mense onmiskenbaar die gang van sake in verhalende gedeeltes van die Ou Testament gunstig of ongunstig kan beïnvloed, en dikwels ' $n$ ingrypende wending in die verloop van gebeure bewerkstellig. 
Maar wat van die Nuwe Testament? 'n Ontleding van Lukas se beskrywing van die Handelinge van die Apostels het aan die lig gebring dat persoonlike emosies van die rolspelers ook hier ' $n$ ingrypende uitwerking op gebeure in die eerste eeu $\mathrm{nC}$ het $^{3}$. Sekere emosies het 'n onmiskenbaar negatiewe invloed: Die afgryslike gevolge van woede $(21 \%$ van die opgetekende gevalle) word dramaties geillustreer wanneer die volk, die familiehoofde en Skrifgeleerdes só opgesweep word teen Stefanus dat hul op die tande kners, hom uit die stad uitsleep en hom met klippe doodgooi (Hand 7:5660 ). Woede en haat jeens Paulus lei tot die een aanslag na die ander van die kant van die Jode - eers dié in Damaskus wat 'n komplot smee om hom te vermoor (9:23-29), dan dié in Tessalonika wat die gepeupel teen hom aanhits (17:13), gevolg deur die Jode in Korinthe wat hom hof toe sleep (18:12), en dan weer in Jerusalem waar hy in lewensgevaar verkeer (21:27 ev). 'n Onderlinge geskil tussen Paulus en Barnabas oor Johannes Markus, laat hul in woede uitmekaar gaan (15:39), terwyl Paulus, die prooi van die woede van die eienaars van die waarsêende slavin, gegésel en in die tronk gegooi word omdat hy die waarsêende gees uit haar verdryf het (16:16-23). Haat en afguns van die hoëpriester en Sadduseërs lei tot die gevangeneming van Paulus (5:17), van Stefanus (6:12), en van Jason (17:5-9), en ook tot Paulus se steniging (14:19). Ook ontsteltenis kan negatiewe gevolge

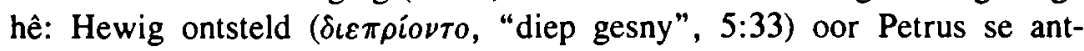
woord, wou die Joodse Raad hom doodmaak, en ontsteltenis, gemeng met woede, lei tot die steniging van Stefanus (7:54). Die hoogmoed van koning Herodes is die oorsaak van sy val: Trots en selfvoldaan weens sy verheerliking deur die gepeupel, word hy deur wurms verteer, en sterf grusaam (12:23). Genoemde voorbeelde ruk mens tot stilstand: Is dit moontlik dat emosies tot sulke totaal irrasionele en skokkende dade aanleiding kan gee?

Sekere emosies is in bepaalde gevalle uiteraard reaktief en het 'n onbeduidende invloed op gebeure: Lukas meld bloot die verbasing van die skare oor Paulus se prediking ( $\dot{\varepsilon} \xi i \sigma \tau \alpha \nu \tau o, 9: 21$ ), noem hoedat die gelowige Jode verstom was dat die Heilige Gees ook op nie-Jode uitgestort is $(\dot{\xi} \xi \varepsilon \sigma \tau \eta \sigma \alpha \nu, 10: 45)$, en dat die gelowiges uit die veld geslaan was toe Paulus onverwags aan die deur klop na sy vrylating uit die tronk ( $\dot{\xi} \xi \dot{\varepsilon} \sigma \tau \eta \sigma \alpha \nu, 12: 16$ ). Die blydskap van die apostels toe die Joodse Raad hul vrylaat, word slegs genoem ( $\chi \alpha i \rho o \nu \tau \varepsilon \varsigma, 5: 41$ ), so ook die vreugde van die bekeerlinge van Antiochië, ( $\dot{\varepsilon} \pi \lambda \eta \rho \circ \hat{\nu} \nu \tau o ~ \chi \alpha \rho \hat{\alpha} \varsigma, 13: 52)$, en van die gelowiges oor die bekering van heidene (15:31), asook die blydskap van die gedoopte tronkbewaarder ( $\dot{\eta} \gamma \alpha \lambda \lambda \iota \dot{\alpha} \sigma \alpha \tau o, 16: 34)$. Ook vrees kan 'n blote 
reaksie wees, soos wanneer almal vreesbevange is ná Ananias en Saffira se

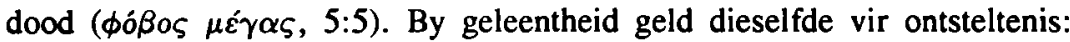
Nadat die storm dae lank op see gewoed het, sê Lukas bloot dat alle hoop op redding hul verlaat het (27:20). Ook droefheid en berou is meesal die gevolg en nie die oorsaak van gebeure nie: Daar was groot smart oor die

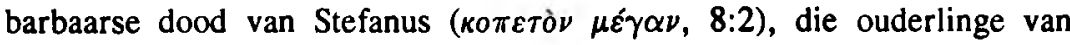
Efese was baie hartseer omdat Paulus gesê het hul sou hom nooit weer sien nie ( $\dot{\delta} \delta \nu \nu \dot{\omega} \mu \varepsilon \nu o \iota \mu \dot{\alpha} \lambda_{\iota} \sigma \tau \alpha, 20: 38$ ), en die gelowiges het gehuil toe Agabus profeteer dat Paulus geboei en aan die heidene uitgelewer sou word

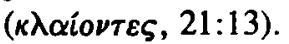

Dit blyk egter ook uit Lukas se verhaal dat emosies 'n besonder positiewe uitwerking op gebeure kon hê: Op pinksterdag word drie duisend mense gedoop en danksy hul vrees en ontsag ( $\phi o ́ \beta o s, 2: 43$ ), was hulle eensgesind ( $\dot{o} \mu \sigma \theta v \mu \alpha \delta \dot{o} \nu, 2: 46)$ en het alles met mekaar gedeel. Uit vrees vir die volk gebruik die bevelvoerder van die tempelwag en sy manne geen geweld teen die apostels nie (5:26). Toe die stadsbestuur hoor Paulus en Silas is Romeinse burgers, skrik hulle groot en uit vrees dat hul die wet oortree, vra hulle verskoning en laat die apostels vry ( $\dot{\varepsilon} \phi o \beta \eta \dot{\eta} \theta \eta \sigma \alpha \nu, 16: 38$; vergelyk ook $\phi o \beta \eta \theta \varepsilon i \varsigma, 23: 10$ ). As Cornelius in 'n gesig 'n engel van God

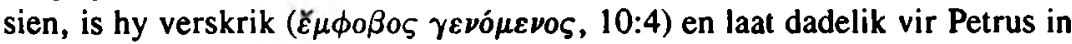
Joppe haal. Dit kan wees dat ons hier die eerste opgetekende geval het van die emosie van vrees wat 'n deurbraak bewerkstellig in die verspreiding van die evangelie aan die heidene. Die rol van angs in die tronkbewaarder

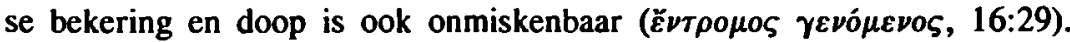
Toe dit blyk dat Paulus 'n Romeinse burger was, skrik die Romeinse bevelvoerder groot ( $\dot{\varepsilon} \phi \circ \beta \dot{\eta} \theta \eta, 22: 29$ ), en hy gee aan Paulus die geleentheid om die priesterhoofde en die Joodse Raad toe te spreek: 'n Emosie skep die geleentheid vir die verspreiding van die opstandingsboodskap (23:6)! Dikwels gee verbasing 'n positiewe wending aan gebeure: Dis besonder opvallend dat op pinksterdag juis die verwondering en verbasing van die skare ( $\dot{\xi} \xi i \sigma \tau \alpha \nu \tau o, 2: 7,12 ; \dot{\varepsilon} \theta \alpha \dot{v} \mu \alpha \zeta o \nu, 2: 7)$ regstreeks aanleiding gee tot Petrus se beroemde rede, en sy toehoorders, ontvanklik maak vir sy raad om hul te bekeer en hul te laat doop (2:38). Sowat 3000 gee gehoor! Vervul met verwondering oor die genesing van 'n verlamde $(\dot{\varepsilon} \pi \lambda \dot{\eta} \sigma \theta \eta \sigma o \nu$

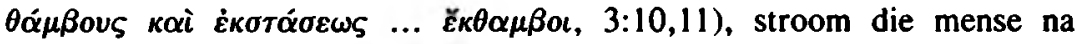
Petrus en Johannes, oop en ontvanklik vir die verlossingsboodskap (3:1226). Verbaas ( $\dot{\varepsilon} \xi i \sigma \tau \alpha \tau$, 8:13) oor die wondertekens van Filippus kom Simon die towenaar saam met ander tot geloof en laat hul doop. Kan daar teen die agtergrond van hierdie insident nog twyfel bestaan oor die merkwaardige rol van emosies in die proses van evangelisasie, berou en beke- 
ring? Blydskap kring uit, en as die kreupele emosioneel en ongeïnhibeerd, springend en juigend uiting gee aan sy vreugde en lofprysing (3:8), word almal met verbasing vervul (3:10). Verheug dat Paulus en Barnabas na hulle kom ( $(\varepsilon \alpha \iota \pi o \nu, 13: 48)$, verheerlik die heidene die woord van die Here en word gelowig. Lukas vervolg met hierdie betekenisvolle mededeling: "Die woord van die Here het dwarsdeur die hele streek versprei" (13:49) klaarblyklik danksy 'n emosie wat kollektief ervaar is. Die rol van entoesiasme in die proses van bekering mag nie onderskat word nie: In Berea het die Jode die woord met entoesiastiese belangstelling bestudeer ( $\mu \varepsilon \tau \grave{\alpha}$ $\pi \dot{\alpha} \sigma \eta \varsigma \pi \rho 0 \theta u \mu i \alpha \varsigma, 17: 11)$ en gevolglik het baie gelowig geword (17:12). Lukas se beskrywing van Apollos is besonder insiggewend: Nie alleen was hy 'n begaafde spreker met 'n deeglike kennis van die Skrif nie (18:24), maar ook het hy met groot geesdrif gepraat - letterlik borrelend van gees ( $\zeta \dot{\varepsilon} \omega \nu \tau \hat{\varphi} \pi \nu \varepsilon \dot{v} \mu \alpha \tau \iota, 18: 25)$, mense noukeurig van Jesus geleer, en die Jode

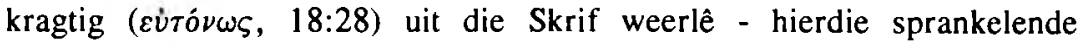
getuigskrif onderstreep die belangrike rol van emosie in kombinasie met noukeurige Skrifuitleg en gepaard met kragtige weerlegging van argumente teen die blye boodskap - voorwaar 'n voortreflike rolmodel vir enige bedienaar van die Woord wat sy prediking ernstig opneem.

In Lukas se verhaal kom 'n opvallende tendens na vore: Emosionele handelinge téén die apostels wat aanvanklik negatiewe resultate het, skep telkens geleenthede vir die verkondiging van die Evangelie, en hierdeur is die tweedefase effek besonder positief. So ook word emosionele verset teen prediking dikwels teenproduktief en bevorder op ironiese wyse juis die objek wat dit veronderstel was om te bestry. Wanneer talle ernstige klagtes voor goeweneur Felix teen Paulus gelê word (25:7), beroep hy hom op die Romeinse keiser, en 'n negatiewe situasie word in 'n positiewe geleentheid omskep om voor die keiser te verskyn (25:12). 'n Emosionele uitbarsting van Festus ( $\mu \varepsilon \gamma \alpha \dot{\lambda} \lambda \eta \tau \hat{\eta} \phi \omega \nu \hat{\eta}, 26: 24)$, gee, teén alle verwagtings in, vir Paulus die kans om 'n simpatieke Agrippa te woord te staan (26:27-32). Die hoëpriester en 'n aantal Sadduseërs was met afguns vervul teen die apostels en hul bediening ( $\dot{\varepsilon} \pi \lambda \dot{\eta} \sigma \theta \eta \sigma \alpha \nu \zeta \dot{\eta} \lambda o v, 5: 17$ ) en stop hul summier in die tronk. Tot die intense frustrasie van die hoëpriester en sy ondersteuners, word hulle egter die nag deur ' $n$ engel bevry en sit hul onderrig voort (5:21). Hulle word voor die Raad gebring - en dit bied hul die geleentheid vir 'n onbevange en uitgesproke getuienis (5:29-32). Stefanus, die slagoffer van die afguns van lede van die Sinagoge, word deur 'n opgesweepte skare gegryp en voor die Raad gebring - wat 'n geleentheid, en wat 'n kragtige getuienis sonder weerga (7:2-53). In Antiochië, en toe in Ikonium, het die Jode weens hul afguns en haat jeens Paulus en Barnabas 
( $\dot{\varepsilon} \pi \lambda \dot{\eta} \sigma \theta \eta \sigma \alpha \nu \zeta \dot{\zeta} \lambda o v, 13: 45)$, die apostels gedwing om pad te gee en hul prediking op die heidene toe te spits - die aanvanklike negatiewe gevolge van emosionele aanslae, het 'n geseënde tweedefase nadraai vir die evangelie-verkondiging (13:48; 14:7. Vergelyk ook 14:19,20). Vererg en

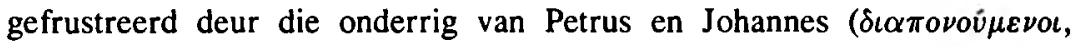
$4: 2$ ), gooi die priesters en Sadduseërs hul in die tronk en daag hul die volgende dag voor 'n uitgelese vergadering: En nou word die negatiewe effek van 'n emosionele handeling omgeswaai tot 'n gulde geleentheid vir Petrus om "vol van die Heilige Gees" kragtig te getuig $(4: 8-12,19,20)$. Die minagtende verguising van die kant van die Korintiërs dwing Paulus om sy prediking tot die heidene te rig $(\beta \lambda \alpha \sigma \phi \eta \mu o u ́ \nu \tau \omega \nu .18: 6)$, en toe hy in Athene deur filosowe smalend as 'n praatjiesmaker uitgekryt word $(\sigma \pi \varepsilon \rho \mu o \lambda o ́ \gamma o \varsigma, 17: 18)$ en in die openbaar in die Areopagus gekonfronteer word, gryp Paulus die geleentheid met albei hande aan om die Evangelie op sprankelende wyse te verkondig aan Grieke wat dit nog nóbit gehoor het nie (17:22-31). Die voorafgaande laat geen twyfel oor die kardinale rol van emosies nie: Nie alleen maak dit mense ontvanklik vir die evangelie nie, maar lei ook tot die verspreiding daarvan en word instrumenteel in prediking en kragtige getuienis. Kan mens nog twyfel aan die bestaan van 'n meesterplan wat soms ten spyte van menslike emosies, maar dikwels juis danksy hierdie emosies ten uitvoer gebring word?

\section{DIE ROL VAN EMOSIES IN DIE EVANGELIE VOLGENS MATTEUS ${ }^{4}$}

'n Ontleding van die aard en effek van emosies op die verloop van gebeure deur Matteus beskryf, het insiggewende resultate opgelewer. 'n Tiental emosies of groepe emosies is geïdentifiseer en in orde van frekwensie ondersoek. Een honderd agt en sewentig gevalle is gelys waarvan sowat ses en twintig 'n onbeduidende uitwerking op die verloop van sake het, en dit geld veral vir nie-praktiese, reaksie-emosies soos verslaenheid, verlammende vrees, verbasing en droefheid. Wat egter onweerlegbaar aan die lig kom, is dat emosies deurentyd die reaksies, die woorde, die dade en verhoudings van die rolspelers bepaal en beïnvloed, dikwels op aangrypende, maar ook op ingrypende wyse.

Hierdie stelling kan gestaaf word met die volgende oorsig oor die rol van emosies in Matteus: Dis enersyds opmerklik dat die woede 5 van opponente telkens deur Jesus as aanknopingspunt vir onderrig benut word en dus ' $n$ tweedefase gunstige uitwerking het, en andersyds, dat Hyself dikwels kwaad word, maar dat sy eie toorn dan gesublimeer word in vermaning en onderrig. 
Verslaenheid en ontsteltenis ${ }^{6}$ het soms negatiewe, selfs tragiese gevolge. Die uitwerking is egter oorwegend positief veral wanneer moedeloosheid in soveel gevalle meebring dat mense hul na Jesus wend om hulp en genesing. Jesus self skroom nie om in vlymskerp taal uiting te gee aan sy frustrasie nie.

Die positiewe en negatiewe uitwerking van vrees is min of meer gelykop verdeel - dikwels danksy 'n gunstige tweedefase wending?. Veral die emosionele Petrus tree dikwels in vrees irrasioneel en kompulsief op. Buiten in Getsemane is Jesus vreesloos. Vrees word telkens instrumenteel in die uitvoering van Gods plan - deur die vrees van die sterrekykers en van Josef vir Herodes word die Kindjie se lewe gered.

Liefde en deernis is die oorheersende emosie van Jesus - in ses en twintig uit die sewe en veertig opgetekende gevalle is sý emosies ter sprake. Dit word deurentyd in liefdesbetoning en genesings gemanifesteer waardeur sy reputasie vir deernis wyd en syd gevestig word.

Te oordeel aan Matteus se siening, het die priester- en familiehoofde, maar veral die Fariseërs, 'n monopolie op haat en afguns (twaalf uit dertien gevalle). Hierdie emosies is die dryfkrag agter die aanslae op Jesus. Telkens omskep Hy dit egter in 'n geleentheid om nie slegs tereg te wys en sy opponente woordeloos te laat nie, maar ook om te onderrig en te verkondig.

Verbasing is in hoofsaak ' $n$ emosie wat kollektief ervaar word en kan bloot reaktief wees, sonder enige beduidende effek. Verwondering is die emosie wat by uitstek die skare ontvanklik maak vir die boodskap van verlossing, en dit speel 'n sleutelrol in aanbidding.

Aan blydskap word daar telkens deur kleiner groepe of individue hoorbaar en sigbaar uiting gegee, ook deur Jesus in sy volledige mensheid, terwyl vreugde aanspoor tot getuienis.

Hoogmoed kom by individue voor en het 'n negatiewe uitwerking. Daarenteen is minagting veral 'n groepsemosie wat kollektief uiting vind in spot, smaad en beswaddering van Jesus.

Berou lei tot inkeer, terwyl droefheid meesal bloot reaktief is, en of kollektief geuit of intiem persoonlik deurleef word.

Ten opsigte van die persone en groepe wat bogenoemde emosies in Matteus se weergawe toon, blyk dit dat die dissipels betreklik selde emosies beleef (sowat vyftien maal), en die skare meer dikwels (vier en twintig maal) - veral emosies soos droefheid, verbasing, moedeloosheid, vrees, woede en minagting. Dis opvallend dat daar meer as ses en twintig gevalle is waar die Fariseërs, die Skrifgeleerdes en die priester- en familiehoofde se emosies hul tot aksie aanspoor, feitlik uitsluitlik negatiewe 
aksie (negentien maal) en gemik teen Jesus. 'n Groot verskeidenheid individue beleef ' $n$ wye spektrum van emosies (ses en veertig gevalle). Dit is egter Jesus as sentrale figuur wie se emosies deurentyd prominent is, véél meer as dié van enige ander rolspeler (sewe en veertig maal), en drie en veertig keer het sy emosies daadwerklik positiewe resultate. Dis treffend, maar geensins verrassend nie, dat in ses en twintig van die sewe en veertig gevalle dit Jesus se liefde en deernis is wat in aksie is.

Hierdie bevindinge rondom die emosies van Jesus self is die fokus van die hieropvolgende ondersoek.

\section{JESUS: SY BELEWING EN VERWERKING VAN SY EMO- SIES}

Daar is velerlei persepsies oor Jesus, oor sy geaardheid en die soort mens wat Hy was. Soos reeds genoem, is dit 'n vry algemene opvatting dat $\mathrm{Hy}$ 'n ernstige mens was en maar selde uiting aan sy gevoelens gegee het - 'n keer toe sy vriend Lasarus dood is, het Jesus gehuil; Hy was kwaad vir die handelaars en geldwisselaars in die tempel en het hul uitgejaag; in Getsemane op die vooraand van sy dood, was Hy benoud en beangs, en aan talle mense het Hy liefde betoon. Dis moontlik dat hierdie persepsie deels toe te skryf is aan die opvatting dat Jesus tog maar eintlik halfgod, bo-natuurlik, 'n soort "super"-mens was. En tog sê Johannes: "Die Woord ( mens $(\sigma \dot{\alpha} \rho \xi)$ geword en tydelik tussen mense kom woon ( $\dot{\varepsilon} \sigma \kappa \dot{\eta} \nu \omega \sigma \varepsilon \nu \dot{\varepsilon} \nu$ $\dot{\eta} \mu \hat{\imath} \nu)(1: 14)$ ". Jesus was dus 'n gewone mens onder mense. Die bestudering en ontleding van sy gevoelens, sy hantering en beheersing daarvan, en die uiting wat Hy aan sy emosies gee, móét eenvoudig 'n bydrae lewer tot die regte perspektief op Jesus, sy aard, sy mensheid en sy bediening op aarde, maar veral ook op Jesus as rolmodel vir die gelowige.

Die ondersoek bevestig - weliswaar geensins verrassend nie - dat 'n aantal negatiewe emosies beperk is tot ander rolspelers en glad nie by Jesus voorkom nie, te wete haat en afguns, hoogmoed en minagting, agterdog en hebsug. Ondanks versoekings, ondanks tarting en verguising behou $\mathrm{Hy}$ rasionele beheer oor kompulsiewe gevoelens en staan Hy uit as voorbeeld, as exemplum en rolmodel.

Enkele emosies kom by wyse van uitsondering by Jesus voor: Die emosioneel gelaaide slotepisode van Jesus se lewe demonstreer onweerlegbaar sy volledige mensheid, want in Getsemane, op die vooraand van sy kruisiging, oorval 'n doodsangs vir Jesus wie se lewe en bediening tot nog toe vreesloos was. Hy verkeer onder onbeskryflike stres en is hoogs emosioneel: Matteus gebruik nie minder nie as vyf uitdrukkings in sy poging 
om reg te laat geskied aan Jesus se lyding (26:37-39): Hy was bedroef $(\lambda \nu \pi \varepsilon \hat{\varepsilon} \sigma \theta \alpha \iota)$, Hy was hoogs ontsteld ( $\dot{\alpha} \delta \eta \mu o \nu \varepsilon \hat{\nu} \nu)$, en sy siel tot die dood toe

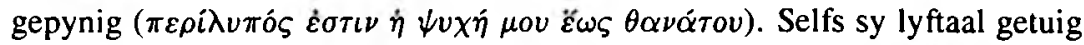
van sy angs en leed as Hy op sy gesig neerval ( $\ddot{\varepsilon} \pi \varepsilon \sigma \varepsilon \nu \dot{\varepsilon} \pi i \pi \rho o \sigma \omega \pi \sigma \nu)$ en

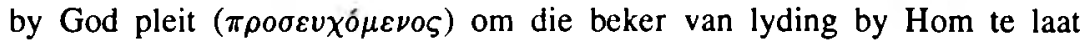
verbygaan. Sy rasionele, byna bo-menslike beheersing van sy emosies blyk onmiskenbaar: In plaas van emosioneel in duie te stort, onderwerp Hy Hom aan God se wens met die woorde "mits dit moontlik is" ( $\varepsilon i \delta v \nu \alpha \tau o ́ \nu$ $\dot{\varepsilon} \sigma \tau(\nu)$, en kwalifiseer uitdruklik: "Nie soos Ek wil nie, maar soos U" ( $\pi \lambda \dot{\eta} \nu$ oì $\chi \dot{\omega} \varsigma \dot{\varepsilon} \gamma \dot{\omega} \theta \dot{\varepsilon} \lambda \omega \dot{\alpha} \lambda \lambda^{\prime} \dot{\omega} \varsigma \sigma u ́$ ). 'n Rukkie later, nadat Hy 'n tweede keer gaan bid het, laat $\mathrm{Hy}$ sy berusting blyk: “My Vader, as hierdie lydensbeker nie by My kan verbygaan sonder dat ek dit drink nie, laat $u$ wil geskied" (26:42). Sy vrees en fisieke angs wat met hierdie emosies gepaardgaan, het egter geen beduidende effek op die daaropvolgende gebeure nie, maar word rasioneel verwerk en gesublimeer in berusting.

Die emosie van verbasing kom twaalf keer in Matteus voor, het oorwegend positiewe gevolge, en is veral die reaksie van die menigte op Jesus se wondergenesings en op sy treffende hantering van vrae en aantygings. By slegs één geleentheid toon Jesus verbasing: As 'n offisier pleit om die genesing van sy slaaf, is Jesus verwonderd oor sy geloof wat sonder weerga was in Israel ( $\dot{\varepsilon} \theta \alpha \dot{v} \mu \alpha \sigma \varepsilon \nu, 8: 10$ ), en die gevolg is dat die slaaf op daardie oomblik gesond geword het $(8: 13)$.

Blydskap kom elf keer voor, en, soos te verwagte, is die uitwerking oorwegend positief. By slegs twee geleenthede toon Jesus blydskap: Gefrustreerd oor die gebrek aan begrip by "slim en geleerde mense", is Jesus kennelik verheug dat eenvoudiges die evangelie verstaan, en in hierdie blydskap, prys Hy sy Vader ( $\dot{\varepsilon} \xi o \mu o \lambda o \gamma o \hat{v} \mu \alpha \hat{\imath} \sigma o \iota, 11: 25)$. Toe die dissipels op ' $n$ vraag van Jesus vir Hom vertel wie die mense meen Hy is, vra Jesus: "Maar julle, wie, sê júlle, is Ek?" (16:15). Op Petrus se antwoord: " $U$ is die Christus, die Seun van die lewende God", is Jesus só verheug dat $\mathrm{Hy}$ hom gelukwens ( $\mu \alpha \kappa \alpha ́ \rho \iota \varsigma \varsigma \hat{i}, 16: 17$ ) en voortgaan met die betekenisvolle uitspraak dat Petrus 'n sleutelrol gaan speel ten opsigte van die kerk en die koninkryk van die hemel. Jesus se algehele emosionele ommeswaai net hierna as $\mathrm{Hy}$ in skerp teenstelling met hierdie verklaring, woedend vir Petrus berispe, word later onder woede behandel.

Slegs tien gevalle van droefheid is opgeteken, dikwels in die vorm van berou. Jesus self beleef by drie geleenthede hartseer, maar bloot as ' $n$ reaksie sonder beduidende effek op gebeure. Toe Hy verneem dat Johannes die Doper onthoof is - 'n man vir wie Hy soveel respek gehad het as 'n mens sonder gelyke op aarde (11:11) - gaan Hy weg na 'n verlate plek om

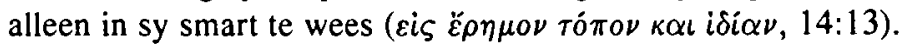


Van Getsemane tot Golgota loop emosies hoog: Die nag voor sy gevangeneming was Jesus hartseer, hoogs ontsteld en diep bedroef. Let op Matteus se stapeling van terme om uitdrukking te probeer gee aan die

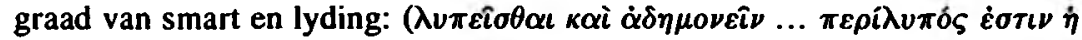
$\psi v \times \dot{\eta} \mu o v, 26: 37,38)$. Deur drie keer alleen in die gebed te gaan worstel, verwerk Hy sy smart en toon toenemende berusting $(26: 39,42,44)$. Jesus se intense hartseer word vererger as Hy met diep teleurstelling ontdek dat sy dissipels weens vleeslike swakheid nie eens één uur met Hom kon waak nie, en nog twee keer hierna deur slaap oorval word. Geen harde woorde val egter, geen verwyte nie - net die retoriese vraag, miskien met 'n tikkie ironie: "Slaap en rus julle nog?"

'n Groep emosies wat vry algemeen voorkom, is verslaenheid, moedeloosheid, ontsteltenis en frustrasie (een en dertig keer, $17.4 \%$ van die totaal van gelyste gevalle). Hierdie emosies word ervaar wanneer dinge 'n negatiewe wending neem en die hoop vervaag dat die situasie mag verander of verbeter. Frustrasie spruit uit 'n mens se gevoel dat 'n skaakmatposisie bereik is en kan tot radikale, selfs gewelddadige optrede aanleiding gee. Die gevolge is soms onbeduidend (vyf keer), meer dikwels negatief (agt keer), maar meesal positief (agtien keer). Hierdie emosie word sowel kollektief as individueel ervaar. Ook Jesus in sy volledige mensheid beleef hierdie gevoelens, en sy verwerking en hantering daarvan is weer eens opvallend. Uit Matteus se verhaal blyk ses sulke insidente. Sekerlik sy aangrypendste en mees emosioneel gelaaide woorde skreeu die sterwende Jesus luidkeels aan die kruis uit: “My God, my God, wáárom het U my verlaat?!” ( $\dot{\alpha} \nu \varepsilon \beta o ́ \eta \sigma \varepsilon \nu . . . \phi \omega \nu \eta \hat{~} \mu \varepsilon \gamma \dot{\alpha} \lambda \eta, 27: 46)$. Kon enige ander woorde méér weerspieël het van sy menslike gevoel van godverlate verslaenheid en moedeloosheid? Hoewel hiér geen sprake is van enige effek op gebeure nie, het al die ander insidente 'n uitwerking: Jesus word kennelik kwaad vir en raak intens gefrustreerd met die dorpe wat hul nie bekeer nie ten spyte daarvan dat Hy die meeste van sy wonderdade daar gedoen het, en met snydende verontwaardiging verwyt Hy eers Gorasin, dan Betsaida en ook Kapernaum: "Ellende wag vir jou! ... Ellende wag vir

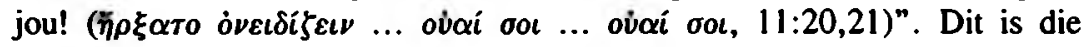
skerpste vorm van kritiek wat Jesus later ook genadeloos aanwend teen die huigelagtige skrifgeleerdes en Fariseërs (23:13-36: hierna onder woede behandel). In sy frustrasie oor die gebrek aan begrip by sy dissipels toe Hy hul gewaarsku het teen die suurdeeg van die Fariseërs en die Sadduseërs, gee Hy uiting aan sy moedeloosheid: "Kleingelowiges! ... Verstaan julle

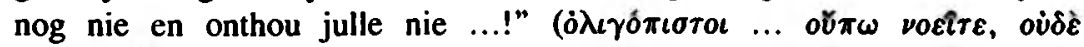
$\mu \nu \eta \mu о \nu \varepsilon \dot{v} \varepsilon \tau \varepsilon \ldots ; 16: 8,9)$. By negatiewe kritiek bly dit egter nie: Trou aan 
sy aard. benut Jesus dic geleentheid, verduidelik, en sorg dat hul sy bedoeling verstaan (16:12). Toe die dissipels nie die geestelik versteurde seun kon genees nie, en sy pa hom in moedeloosheid tot Jesus wend, bereik Jesus se woede en frustrasie met sy dissipels se ongeloof breekpunt en voor almal teenwoordig, bars Hy uit in vlymskerp verwyte: "Ongelowige en ontaarde ( $=$ verdraaide) geslag, hoe lank moet Ek nog saam met

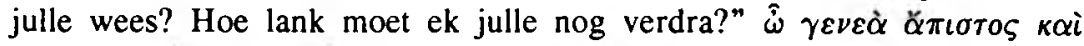

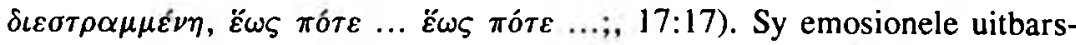
ting word deur die anaphora in sy retoriese vrae in reliëf geplaas, en mens kan dit kwalik mislees - selfs die duiwel moet dit ontgeld, want Jesus dra as 't ware sy woede oor op hom, en, anders as gewoonlik, "het Jesus hom skerp aangespreek" ( $\dot{\varepsilon} \pi \varepsilon \tau i \mu \eta \sigma \varepsilon \nu, 17: 18)^{8}$. Die duiwel verlaat die seun, hy word gesond, en die episode het 'n positiewe afloop. Op die Sadduseërs se strikvraag oor die sewe broers, die vrou en die opstanding, reageer Jesus skerp en met verontwaardiging: "Julle dwaal omdat julle nie

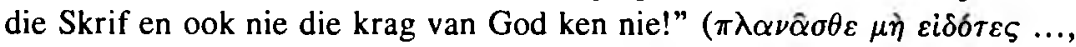
22:29). Deur sy skerp kritiek gerig juis teen hul gewaande kennis, pluk Hy die mat onder hul uit en snoer hul die mond ( $\dot{\varepsilon} \phi i \mu \omega \sigma \varepsilon \nu, 22: 34)$ - maar nie sonder om die onderriggeleentheid weer eens positief te benut en die skare verslae te laat oor sy antwoord nie: ( $\dot{\varepsilon} \xi \varepsilon \pi \lambda \dot{\eta} \sigma \sigma o \nu \tau o, 22: 33)$ : "Hy is nie die God van dooies nie, maar van lewendes" (22:32). Deur sy taktiese antwoord systap Hy die strikvraag van die Sadduseërs wat nie in die opstanding glo nie.

Met die deurlees van Matteus se verhaal, is daar 'n emosie wat mens nie normaalweg met Jesus assosieer nie, 'n emosie wat Hy veel meer openbaar as enige ander individu of groep: Dit is die emosie van woede. In veertien uit die vier en dertig gelyste insidente is dit Jesus wat aan hierdie emosie uiting gee. Sy woede word egter feitlik sonder uitsondering positief gesublimeer in vermaning en onderrig. Sekerlik die insiggewendste episode aan die begin van Jesus se aktiewe bediening, is wanneer die Gees Hom die woestyn inlei om deur die duiwel versoek te word. Jesus is pas deur Johannes gedoop en God het sy status verklaar: "Dit is my geliefde Seun. Oor Hom verheug Ek My!" (3:17). Jesus staan op die punt om uitvoering aan sy goddelike opdrag te gee, deeglik bewus van die ontsagwekkende aard en omvang daarvan. Hy het mens geword, met die gevoelens van 'n mens. Na veertig dae en veertig nagte sonder kos, het Hy baie honger soos enige mens (4:2). En dis net hier waar die duiwel Hom versoek om klippe in brood te verander, so maklik... . Beredeneerd wys Jesus hom egter op Deuteronium 8:3. Vervolgens probeer die duiwel Hom verlei om van die tempel se dak af te spring - wie weet, dalk het Jesus as mens nie 
kans gesien vir die taak wat op Hom wag nie - en die duiwel haal nou self ook aan uit Psalm 91:11 en 12. Wéér reageer Jesus bedaard aan die hand van Deuteronium 6:16. Deur kalm beredeneerde sitate uit die Woord, word die duiwel egter nie van stryk gebring nie, en 'n derde keer versoek hy Jesus: "Ek sal jou al die koninkryke in die wêreld gee - val net neer en aanbid my!" Genoeg is genoeg, en dié keer vererg Jesus Hom en spreek die duiwel skerp aan: "Gaan weg, Satan!" (ï $\pi \alpha \gamma \varepsilon, \sigma \alpha \tau \alpha \nu \hat{\alpha}, 4: 10)$. Dis opvallend en veelseggend dat die duiwel Hom dié keer met rus laat en dat hy dadelik padgee wanneer hy emosioneel en kragtig gekonfronteer word. 'n Sterker term as die aoristus imperatief van $i \pi \alpha ́ \gamma \omega$ is moeilik denkbaar veral as die grondbetekenis van hierdie woord in ag geneem word, te wete "om iemand ondergeskik te maak aan gesag, om iemand aan die regterstoel te onderwerp". Wat Jesus dus die duiwel hier skerp toevoeg, is: "Onderwerp jou aan die oppergesag en regspraak van God, Satan!" Sy onmiddellike reaksie ( $\dot{\alpha} \phi i \eta \sigma \iota \nu$ in die historiese praesens en nie in die aoristus vir eenmalige handeling nie, 4:11), is nie maar net "met rus laat" nie, maar is gelaai met veelseggende betekenis: "Toe gee die duiwel op en blaas blywend die aftog". Deur sy skerp emosionele reaksie word Jesus se voortgesette en finale triomf oor duiwel en dood hier ingelei in 'n dramatiese overture tot sy aktiewe bediening. Is dit vreemd dat Jesus hierna volgens Matteus nóóit weer op soortgelyke wyse deur die duiwel versoek word nie?

Matteus beskryf etlike insidente waarin Jesus vir mense, onder wie sy dissipels, kwaad word. Toe 'n raadslid van die sinagoge Jesus vra om sy sterwende dogtertjie te genees en Hy by sy huis kom, sien Hy die klomp mense emosioneel te kere gaan. Klaarblyklik geirriteerd, jaag Hy hulle uit ( $\dot{\alpha} \nu \alpha \chi \omega \rho \varepsilon i \tau \varepsilon, 9: 24)$. So word 'n toneel van kalmte voorberei, Jesus gaan in, en in deernis wek Hy die dogtertjie op uit die dood (9:25). Kwaad vir die dorpe waarin $\mathrm{Hy}$ die meeste van sy wonderdade gedoen het, verwyt $\mathrm{Hy}$

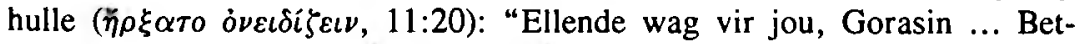

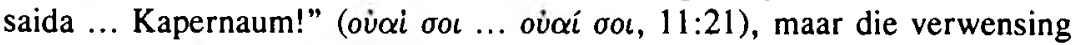
bied, soos só dikwels gebeur, die aanknopingspunt vir prediking oor bekering en oordeel (11:21-24). Op dramatiese wyse gee Jesus uiting aan sy woede wanneer Petrus Hom berispe omdat Hy na Jerusalem wil gaan ... om doodgemaak te word. Jesus reageer skerp: "Gee pad na agter My,

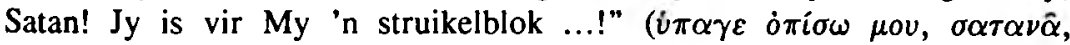
16:23). Jesus kon geswig het voor die versoeking van hierdie "wolf in skaapsklere", maar 'n emosionele standpuntinname help Hom die struikelblok oorkom, die insident het 'n positiewe afloop, en Gods plan word nie ontspoor nie. Kwaad en gefrustreerd toe sy dissipels nie 'n geestelik 
versteurde seun kon genees nie, verwyt Hy hulle in geen onduidelike terme

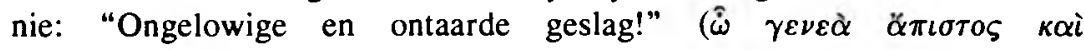

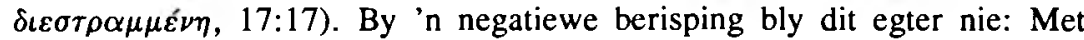
geloof soos 'n mosterdsaadjie, sal niks vir julle onmoontlik wees nie! (17:20). Seker die bekendste insident waarin Jesus fisiek uiting gee aan sy woede, vind plaas as $\mathrm{Hy}$ die handelaars uit die tempel uitjaag, die tafels van die geldwisselaars en stoele van die duiweverkopers omgooi

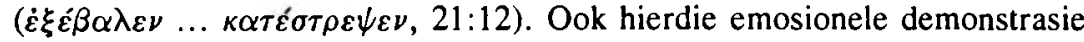
van sy toorn word getemper deur die rasionele motivering en vermaning "My huis sal 'n huis van gebed wees" (21:13).

In die oorgrote meerderheid van gevalle waar die emosie van woede van mense besit neem, gaan dit, soos mens kan verwag, oor in 'n negatiewe handeling (22 uit 34). Jesus se woede het egter slegs in één geval 'n negatiewe effek: $\mathrm{Na}$ 'n uiters stresvolle paar dae is Jesus vroeg een oggend op pad van Betanië terug Jerusalem toe. Honger stap Hy vol verwagting na 'n vyeboom langs die pad. Wat was sy teleurstelling groot toe Hy slegs blare daaraan kry. In sy intense frustrasie vervloek Hy die boom: "Mag daar nóóit tot in ewigheid vrugte uit jou voortkom nie!" (21:19). Die vyeboom het dadelik verdroog, en ons deel in die dissipels se verbasing. Vanuit ons perspektief op Jesus as mens, as 'n mens met emosies, is sy optrede egter so begryplik: Die stres, die honger, die verwagting, die teleurstelling - alles die gewaarwordinge eie aan 'n gewone mens. Is sy woede en vervloeking van die boom dan vreemd? Kan daar 'n duideliker bewys wees dat Jesus volledig mens geword het en dus vir my met mý gevoelens verstaan?

As daar iets is wat Jesus by herhaling briesend gemaak het, was dit huigelary. In sy gelaaide bergrede rig Hy Hom in skerp taal met snydende sarkasme tot die selfvoldane mens: "Huigelaar! Haal eers die balk uit jou

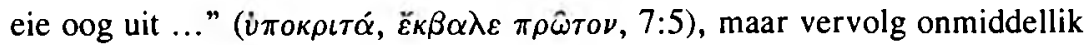
met die sinvolle, logiese en opbouende motivering: "dan sal jy goed kan sien om die splinter uit jou broer se oog uit te haal". Wanneer die dissipels in angs vir die storm Jesus wakkermaak, spreek Hy die wind en die weer hard en verwytend aan ( $\dot{\varepsilon} \pi \varepsilon \tau i \mu \eta \sigma \varepsilon \nu, 8: 26)$. Dis opvallend dat 'n skerp woord deur die emosie van verontwaardiging voortgebring, besonder effektief is, selfs ten opsigte van die elemente, want dit het doodstil geword. Jesus se aanvoelbare woede jeens die Fariseërs is 'n herhalende motief: Snydend kritiseer Hy hul onvermoë om goeie vrugte voort te bring en benadruk sy woede deur gebruik te mak van dieselfde aanspreekvorm as Johannes die Doper vroeër: "Julle addergebroedsel! ( $\gamma \varepsilon \nu \nu \eta \mu \alpha \tau \alpha$

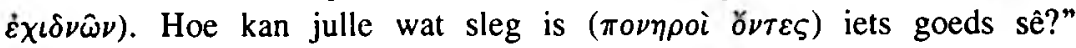


(12:34). Op kenmerkende wyse benut Hy egter weer eens die onderrigmoment om te maan dat elkeen op die oordeelsdag op grond van sy woorde beoordeel sal word $(12: 36,37)$. Toe skrifgeleerdes en Fariseërs 'n wonderteken van Jesus vra, weier Hy en betig hulle as 'n slegte en afvallige geslag

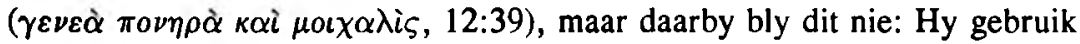
die geleentheid as aanknopingspunt om die toehoorders oor die opstanding te onderrig (12:39-42). As die Fariseërs en skrifgeleerdes sy dissipels kritiseer omdat hulle nie hul hande was as hul gaan eet nie, kap Jesus heftig terug: "Waarom verontagsaam julle sélf die gebod van God...?

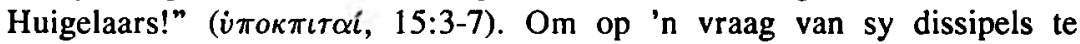
demonstreer wie die belangrikste in die koninkryk van die hemel is, roep Jesus 'n kindjie nader, en ' $n$ treffende toneel speel hom af: Vol deernis vir die kleintjies, maar met latente woede verdoem $\mathrm{Hy}$ by voorbaat elkeen wat hul laat struikel of aanstoot gee $(\sigma \kappa \alpha \nu \delta \alpha \lambda i \eta)$ : "Dit is gepas $(\delta \nu \mu \phi \varepsilon \rho \varepsilon \varepsilon)$ dat 'n groot meulsteen om sy nek gehang word (passief: $\kappa \rho \varepsilon \mu \alpha \sigma \theta \hat{n}$ ) en hy in die diep see verdrink, word" ( $\kappa \alpha \tau \alpha \pi \sigma \nu \tau \iota \sigma \theta \hat{n})(18: 6)$. Dit is jammer dat onder andere dié Afrikaanse vertaling nie reg laat geskied aan die straf waaraan die booswig passief onderwerp moet word nie: "vir hom is dit beter as hy met 'n groot meulsteen aan sy nek in die diep see verdrink" (aktief). Durf enigeen dit betwis dat Jesus hier onomwonde Hom uitspreek ten gunste van eliminering uit die samelewing, selfs die doodstraf, vir kindermolesteerders en kinderverkragters? In sterk emosionele terme gee Hy uiting aan sy toorn teen enigiets wat afvalligheid of struikeling bring:

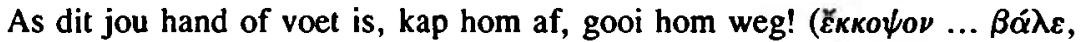
18:8); as dit jou oog is, ruk hom uit, gooi hom weg! ( $\check{\xi} \xi \lambda \varepsilon \ldots \beta \dot{\alpha} \lambda \varepsilon$, 18:9). Die aoristus imperatief laat geen twyfel nie dat eenmalige, ingrypende aksie vereis word, sonder sprake van genade. Met kwistige aanwending van die heuningkwas stel die Fariseërs deur hul volgelinge 'n strikvraag aan Jesus oor die belasting. Jesus sien déúr hul valsheid, vererg

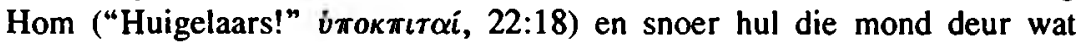
vandag as 'n sprankelende kishou toegejuig sou word: "Gee dan aan die keiser wat aan die keiser behoort en aan God wat aan God behoort!"

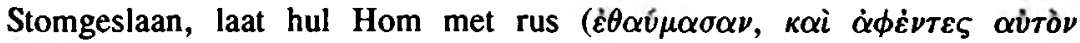
$\dot{\alpha} \pi \hat{\eta} \lambda \theta \alpha \nu, 22: 22)$. By Jesus is daar geen teken van leedvermaak nie.

As iemand nog twyfel aan Jesus se mensheid, sy emosionele aard, sy woede, sy skerp tong en sy bytende sarkasme, lees dan Matteus 23: Jesus waarsku teen die skrifgeleerdes en die Fariseërs weens hul opperste huigelary (23:1-12). Maar dan rig Hy Hom direk tot hulle en met geregverdigde, onverbloemde woede sê Hy hul so sleg dat geen spreekwoorde-

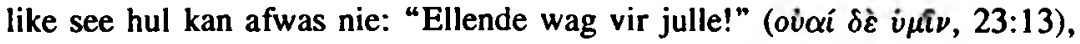


en nie minder nie as ses keer word dit herhaal9. Ov́ai word gevolg deur

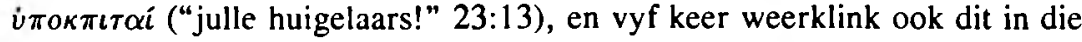
volgende vyftien verse. Die meesleurende assonansie van die oor en oor

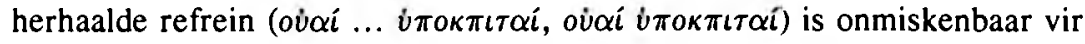
hoorder en leser - onwillekeurig wonder mens: kon daar 'n effektiewer dreunsang ("chant") wees tot groot verleentheid en ontsteltenis en ten koste van die skrifgeleerdes en Fariseërs? Asof dit nie genoeg is nie, kryt Hy hul genadeloos uit as "blinde leiers", "blinde dwase!", "Julle blindes!",

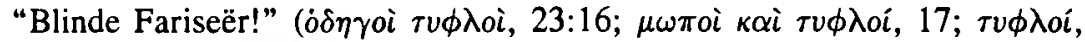
19; $\Phi \alpha \rho \imath \sigma \alpha i \varepsilon \tau \nu \phi \lambda \hat{\varepsilon}, 26)$. Ook hier is die anaphora en die klankeffek van die oi-klanke opvallend en geen blote toeval nie. Nà dit alles, en om die kroon te span, hamer Jesus die welverdiende en reeds bekende verguising onbeskroomd in: ŏ $\gamma \varepsilon \varsigma, \gamma \varepsilon \nu \nu \eta \dot{\mu} \mu \alpha \tau \alpha \dot{\varepsilon} \chi \iota \delta \nu \hat{\omega} \nu$ - "Julle slange, gebroedsel van adders!" (23:33). Na so 'n smaadrede en sulke skeldtaal voel mens dis nodig om eers ' $n$ slag diep asem te haal ..., en onvermydelik kom die besef: Dieselfde woede word ontketen teen die huigelary van elke hedendaagse "gelowige" ..., ook myne.

Uit die voorafgaande ontleding het dit duidelik geblyk dat Jesus nie skroom om uiting te gee aan sy gevoel van woede en irritasie nie en dan dikwels met skerp snydende kritiek vorendag kom: Soos klokslag word sy woede egter positief gesublimeer in vermaning en opbouende onderrig. Dit kan gerig wees teen sy vriend Petrus, teen sy dissipels of ' $n$ irriterende groep mense, teen die elemente, teen die duiwel, maar veral vlymskerp en genadeloos teen die huigelagtige Fariseërs en skrifgeleerdes.

Die laaste emosie, wat dan ook, heel gepas, Jesus se oorheersende emosie is en sy wese karakteriseer, is liefde, deernis en medelye. Liefde het uiteraard feitlik sonder uitsondering 'n gunstige uitwerking omdat dit 'n mens laat neig tot deernis en toenadering. In Matteus se verhaal is ses en twintig gevalle opgeteken waar liefde of simpatie eksplisiet genoem word of implisiet voorkom. Dit verteenwoordig $14.6 \%$ van die total van gelyste emosies. Die opvallendste waarneming is egter dat vyf en twintig van die ses en twintig gevalle die liefde van Jesus demonstreer. Nêrens gee Matteus ' $n$ aanduiding dat hierdie emosies deur ander groepe (Fariseërs, skares, dissipels) of deur individue (buiten Petrus) ervaar word nie. Liefde is by uitstek Jesus se emosie, en wat meer is, dit is sy oorheersende emosie, want van die sewe en veertig gevalle waar emosies van Jesus voorkom, is sy liefde en deernis nie minder nie as ses en twintig keer ter sprake.

Die rol en positiewe effek van Jesus se liefde, simpatie, deernis en aanverwante emosies sal nou aan die hand van opgetekende insidente 
geïllustreer word. Jesus se genesings en weldade kom die eerste keer in Matteus 4:23, vier en twintig ter sprake en wel by wyse van 'n veralgemenende stelling wat die toneel voorberei vir die talle genesings wat volg: "Die mense het toe die siekes met allerhande kwale en pyne, die wat in die mag van duiwels was, geestelik versteurdes en verlamdes na Hom toe gebring, en Hy het hulle gesond gemaak" (4:24). Die uitwerking van hierdie demonstrasies van liefde en deernis is vanselfsprekend sonder uitsondering positief. Die eerste opgetekende geval is dié van 'n melaatse wat smeek om genesing: Jesus gee gehoor aan sy pleidooi met die woorde: "Ek wil. Word gesond!" $(\theta \dot{\varepsilon} \lambda \omega, \kappa \alpha \theta \alpha \rho i \sigma \theta \eta \tau \iota, 8: 3)$. 'n Offisier pleit om genesing vir sy slaaf. In verwondering oor sy geloof ( $\dot{\varepsilon} \theta \alpha \dot{v} \mu \alpha \sigma \varepsilon \nu, 8: 10)$, en in deernis genees Jesus die sieke (8:13) - 'n voorbeeld van emosies in wisselwerking wat 'n positiewe effek het. Jesus genees Petrus se skoonma $(8: 14,15)$ en wéér besef ons die skrywer noem slegs enkele van die tallose gevalle as hy sê: "Hy het die geeste met 'n woord uitgedryf en al die siekes gesond gemaak" (8:16) ${ }^{10}$. Wat opval, is dat die emosie van liefde in diens staan van die vervulling van 'n profesie - dié in Jesaja 53:4: "Hy het ons lyding op Hom geneem, ons siektes het Hy gedra" (8:17). In deernis vergeef Jesus 'n verlamde se sondes (9:2) en, kennelik geïrriteerd met die Skrifgeleerdes wat Hom as godslasterlik beskou, genees Hy boonop die man (9:3-7). Hy genees die vrou met bloedvloeiing, en die manier waarop Hy met haar praat, is sprekend van sy deernis met hierdie jong meisie: "Wees gerus, dogter $(\theta \hat{v} \gamma \alpha \tau \varepsilon \rho)$, jou geloof het jou gered!" (9:22). Elke wondergenesing soos hierdie het nog die bykomstige positiewe effek dat massas mense toekyk en onder die indruk kom van Jesus se liefde vir mense wat swaarkry - wat 'n rolmodel vir navolgers van Christus! Uit die daaropvolgende genesing van Jaïrus se dogtertjie, blyk dit bowendien dat sulke nuus soos 'n veldbrand versprei: "Berigte hieroor het deur daardie hele omgewing versprei" $(9: 26)$.

Die volgende gevalle van genesing word hier slegs kortliks genoem: Jesus genees twee blindes (9:28-30); Hy dryf 'n duiwel uit en 'n stom man kan weer praat (9:33); 'n duiwelbesete blinde en stomme word genees (12:22); 'n Kanaänitiese vrou wie se dogter in die mag van 'n duiwel was, laat haar nie van stryk bring as Jesus haar ignoreer nie en pleit só dringend om genesing dat Hy, diep beïndruk deur haar groot geloof, Hom ontferm en haar wens vervul (15:22-28). Twee blindes buite Jerigo pleit by Jesus: "Ontferm U tog oor ons!" ( $\dot{\varepsilon} \lambda \dot{\varepsilon} \eta \sigma o \nu \dot{\eta} \mu \hat{\alpha} \varsigma, 20: 31)$. Só fisiek en innig kry Jesus hul jammer dat sy ingewande $(\sigma \pi \lambda \dot{\alpha} \gamma \chi \nu \alpha)$ in Hom omkeer ( $\sigma \pi \lambda \alpha \gamma \chi \nu \iota \sigma \theta \varepsilon i \zeta, 20: 34)$, Hy raak hul oë aan, en hulle kan sien, en volg Hom. Al hierdie insidente lewer oorweldigende getuienis vir die positiewe 
gevolge van Jesus se emosionele betrokkenheid vanweë sy liefde en deernis.

Afgesien van die siekes, het Jesus innige medelye ook met die skares, met kinders, en met dié wat afgeknou word. Toe Hy die menigtes sien, "moeg en hulpeloos soos skape wat nie 'n herder het nie", het Hy hul innig jammer gekry ( $\dot{\varepsilon} \sigma \pi \lambda \alpha \gamma \chi \nu i \sigma \theta \eta, 9: 36)$, en, aangespoor deur die emosie van deernis, sê Hy sy dissipels moet bid vir arbeiders om hierdie oes in te samel. Die kousale verband tussen emosie en die redding van mense is onmiskenbaar. Toe ' $n$ groot menigte Hom volg en dit aand word en hul honger was, ver van hul huise, het $\mathrm{Hy}$ hul innig jammer gekry ( $\dot{\varepsilon} \sigma \pi \lambda \alpha \gamma \chi \nu i \sigma \theta \eta, 14: 14)$. Dit bly egter nie by 'n emosie nie, maar Hy voed hulle daadwerklik deur brood en vis te vermeerder (14:17-21). Dit gebeur 'n tweede keer en uit innige medelye ( $\sigma \pi \lambda \alpha \gamma \chi \nu i \zeta o \mu \alpha \iota, 15: 32)$ voed Hy vier duisend mans, afgesien van die vroue en kinders. Op die berg van verheerliking kry ons 'n kykie op Jesus se simpatieke aard wanneer Hy die verskrikte dissipels nie alleen aanspreek nie, maar ook fisiek en gerusstellend aanraak ( $\dot{\alpha} \psi \dot{\alpha} \mu \varepsilon \nu o \varsigma \alpha \dot{v} \tau \hat{\omega} \nu)$ met die woorde: "Staan op en moenie bang wees nie!" (17:7).

Matteus lig die sluier oor Jesus se liefde vir kindertjies wanneer hy beskryf hoe die dissipels raas met die mense wat hulle na Hom gebring het. Sy liefde laat Hom enersyds die dissipels betig en andersyds die kindertjies na Hom toe nooi (19:14). Jesus se liefde vir die mense van Jerusalem skep by Hom die behoefte om hul bymekaar te maak ( $\dot{\varepsilon} \pi\llcorner\sigma \nu \nu \alpha \gamma \alpha \gamma \varepsilon \hat{\varepsilon} \nu)$ "soos 'n hen haar kuikens onder haar vlerke", maar dan blyk sy hartseer en diepe teleurstelling in hul kille reaksie uit sy woorde: "maar hulle wou nie!" (23:37). Wanneer die dissipels met verontwaardiging die verkwisting kritiseer as 'n vrou Jesus met kosbare reukolie salf, reageer Hy met deernis en begrip, betig sy dissipels, tree vir haar en haar goeie daad in die bresse, en benut soos so dikwels die geleentheid tot onderrig (26:6-13). Op 'n dag het Jesus met die mense oor Johannes die Doper gepraat, en sy liefde, waardering en respek vir hierdie sonderlinge en nederige profeet gee aanleiding tot 'n lofrede sonder weerga: "Onder die mense op aarde is niemand gebore wat groter is as Johannes die Doper nie ..." (11:7-14). As Petrus ietwat selfvoldaan bereid is om sy broer tot sewe keer te vergewe, wys Jesus hom, nie neerhalend nie, maar met empatie daarop dat selfs sewentig maal sewe nie genoeg is nie (18:22). 'n Laaste voorbeeld van Jesus se konsidererende sensitiwiteit: Op die vraag van 'n amptenaar waarom Jesus nie tempelbelasting betaal nie, antwoord Hy: Seuns van konings is mos vrygestel (17:26). Maar $\mathrm{Hy}$ is nederig, het ' $\mathrm{n}$ sin vir geregtigheid, en sy inherente deernis maak Hom sensitief vir die mense wat hul onaangename 
plig moet verrig: "Maar ons moenie hierdie mense aanstoot gee nie ... gaan ... betaal hulle die belasting: ( $\mu \grave{\eta} \sigma \kappa \alpha \nu \delta \alpha \lambda i \omega \mu \varepsilon \nu \alpha \dot{v} \tau o u ́ \varsigma, 17: 27)$ ".

Uit die voorafgaande ontleding kom mens oorweldigend onder die indruk van Jesus se oorheersende emosie - sy medelye, liefde en deernis wat bowendien praktiese emosies is wat telkens en telkens weer in besorgdheid, in liefdesbetoning, in dade van genesing en in lering gemanifesteer word.

\section{SLOT: JESUS AS EMOSIONELE ROLMODEL}

In hierdie ondersoek is Jesus se emosies ontleed, sowel die wat eksplisiet deur Matteus genoem word as dié wat onmiskenbaar uit sy uitbeelding van Jesus blyk. Dit het aan die lig gekom dat Jesus 'n wye spektrum van emosies nie alleen beleef het nie, maar dat $\mathrm{Hy}$ emosies rasioneel kon beheer en ook op dramatiese wyse aan sy gevoelens kon uiting gee.

Sy eenmalige belewing van doodsangs in Getsemane gaan oor in berusting. Jesus se verwondering oor die offisier se geloof lei tot die genesing van die slaaf. Die eenvoudiges se begrip van die Evangelie en Petrus se insig in Jesus se ware identiteit ontketen groot blydskap by Hom. Jesus ervaar smart met die dood van Johannes en diepe hartseer en teleurstelling as sy dissipels Hom in Getsemane in die steek laat. Aan die kruis skreeu Jesus sy moedeloosheid en godverlatenheid uit, en in sy intense frustrasie verwyt Hy met snydende verontwaardiging die dorpe wat hul nie bekeer nie. Meermale bars Hy in moedeloosheid uit in vlymskerp kritiek op sy dissipels se ongeloof, of trap Hy die Sadduseërs uit weens hul onkunde - maar telkens benut hy die situasie as 'n onderriggeleentheid. Jesus se kragtigste emosie waaraan $\mathrm{Hy}$ talle kere op dramatiese wyse onbeskroomd uiting gee, is sy woede: Sy woedende uittrap van die duiwel toon merkwaardige resultate. Ook Petrus word as "Satan" uitgekryt, onbekeerde dorpe skerp verwyt, en sy dissipels oor hul ongeloof in venynige taal verwens. Die skreeuende skare word die huis uitgejaag, en handelaars en geldwisselaars sonder seremonie die tempel uitgeboender. Selfs die storm gehoorsaam sy verwyte en 'n vyeboom ontgeld sy woede en word genadeloos vervloek. Huigelary maak Jesus briesend, en snydend kritiseer Hy die Fariseërs, die gebroedsel van adders, omdat hul geen goeie vrugte voortbring nie. Maar - en dis só belangrik - telkens as Hy die huigelagtige, selfvoldane en blinde Fariseërs en skrifgeleerdes betig, heftig terugkap teen hul kritiek, in emosioneel gelaaide terme teen hul uitvaar en hul op sprankelende wyse uitoorlê en woordeloos laat - telkens as dit gebeur, word sy woede soos klokslag getemper en positief gesublimeer in vermaning en opbouende onderrig. 
Dit is egter oorweerlegbaar aangetoon dat Jesus se oorheersende emosie sy liefde en deernis is. Hierdie emosies is by Jesus essensieel praktiese emosies wat oor en oor dramaties gemanifesteer word in liefdesbetoning, in dade van genesing, in besorgdheid en in simpatieke teregwysing. Hierdie dinge is alleenlik moontlik vanweë sy sensitiewe begrip vir die posisie van kindertjies, van mense in angs of onder groot stres.

Kan iemand nog twyfel daaraan dat Jesus volledig mens geword het, die wye spektrum van menslike emosies beleef het, en veral dat Hy ten opsigte van die hantering en uitlewing van emosies dié rolmodel ook vir die gelowige van vandag is? Jesus toon daar is plek vir vrees, daar is ruimte vir verwondering, daar is behoefte aan blydskap en lofprysing. Hy demonstreer dat smart en teleurstelling deel van die lewe is, dat moedeloosheid en frustrasie tot uitbarsting mag kom, maar dan positief verwerk en benut moet word. Hy toon onweerlegbaar die rol van woede jeens die Versoeker, jeens oppervlakkige emosionaliteit, jeens onsensitiwiteit, en jeens kindermishandeling. Hy toon die noodsaak van skerp teregwysing van vriende wat wil verlei, en van snydende kritiek op huigelary, selfvoldaanheid en misbruik van die kerk vir eie gewin. Deurentyd toon Hy egter hoe sulke konfrontasies nie daarby gelaat mag word nie, maar telkens as 'n geleentheid benut moet word vir teregwysing, vermaning, gepaard met opbouende onderrig. Bo alles demonstreer Jesus aan die gelowige sy liefde - 'n besorgde emosionele betrokkenheid en sensitiwiteit wat uiting vind in liefdesbetoning. Wat sou die wêreld sonder Jesus wees? Wat sou die wêreld sonder emosies wees? Die gelowige het albei - en nog meer: Die gelowige het boonop vir Jesus as emosionele rolmodel.

\section{NOTAS:}

1 W W Fortenbauch, Aristotle on Emotion, Duckworth 1975, 79-82, praat van "non-practical" in teenstelling met "practical" emosies.

2 D A Pauw, "The influence of emotions upon events in 1 and 2 Samuel", Pharos 75/1 (1993), 23-42.

3 D A Pauw, "The influence of emotions upon events in the 'Acts of the Apostles'", Pharos 77/1 (1995), 39-56.

4 ' $n$ Uitvoerige ontleding verskyn in 'n (nog ongepubliseerde) artikel: Die invloed van emosies op gebeure in die Matteus-evangelie.

534 gevalle van woede is gelys, dit wil sê $19.1 \%$ uit die totaal.

631 gevalle van hierdie emosies is ontleed, dit wil sê $17.4 \%$.

729 gevalle, $16.3 \%, 12$ positief, 11 negatief.

8 Vergelykbare insidente van uitdrywing: "Gaan (in die varke in)!" (íxó $\gamma \varepsilon \tau \varepsilon$,

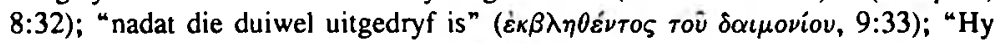

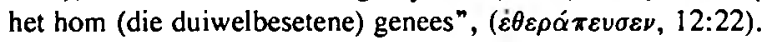

9 Verse $14,15,23,25,27$ en 29. 
10 Vergelyk soortgelyke stellings in 9:35 en 15:30-31. Die frekwensie van liefde sou dus nog veel hoër kon gewees het, maar Matteus verkies om slegs verteenwoordigende insidente op te teken. 